\title{
FEATURE \\ How did the Passaic River, a Superfund site near Newark, New Jersey, become an Agent Orange dioxin TCDD hotspot?
}

Kenneth R. Olson and Mike Tharp

$\mathrm{T}$

he Passaic River name was derived from an Algonquian word meaning "peaceful valley." In the mid-1900s, this peaceful valley in New Jersey, United States, became a major exporter of a powerful herbicide, Agent Orange, which was used as a chemical weapon during the Vietnam War. The unintended consequences of the use of this deadly herbicide were often fatal to military personnel, chemical plant workers, and Vietnamese civilians (Thomas and Kang 1990; Schecter et al. 1995). Those affected in some way by Agent Orange number in the millions (NAS 1974; Schecter et al. 1995). Moreover, evidence is mounting that the effects of exposure to Agent Orange linger through generations of people (Institute of Medicine 1994; Constable and Hatch 1985; Stockbauer et al. 1988). Additionally, in the United States, one of the most massive environmental cleanups in history-costing billions of dollars-has been necessary to try to protect residents of New Jersey and neighboring areas from the lasting impacts of the Agent Orange chemical manufacturing plant on the Passaic River.

The current 2,3,7,8-tetrachlorodibenzodioxin $\left(\mathrm{C}_{12} \mathrm{H}_{4} \mathrm{Cl}_{4} \mathrm{O}_{2}\right.$; TCDD) pollution in the Passaic River dates back to the 1940s, well before the Vietnam War when the US military used Agent Orange to kill jungle vegetation and Vietnamese food crops including cassava (Manihot esculenta), maize (Zea mays), sweet potato (Ipomoea batatas), and nuts. However, Agent Orange was ineffective when sprayed on the South Vietnam rice (Oryza sativa) crop. Agent Blue, the arsenic (As) based rice killer was used on the rice paddies.

A company called Diamond Alkali manufactured Agent Orange in its Newark factory, which was next to the Passaic River. The contaminants - spilled, washed, or leaked Agent Orange-drained into the Passaic River via trenches and pipes. The chemical plant has now been destroyed and contaminated soil incinerated. However, the Passaic River has become a Superfund site, and cleanup costs to date total US $\$ 1.3$ bil-

\section{Figure 1}

New York Harbor and the location of the storm surge barrier locations in Long Island Sound and Lower New York Bay.

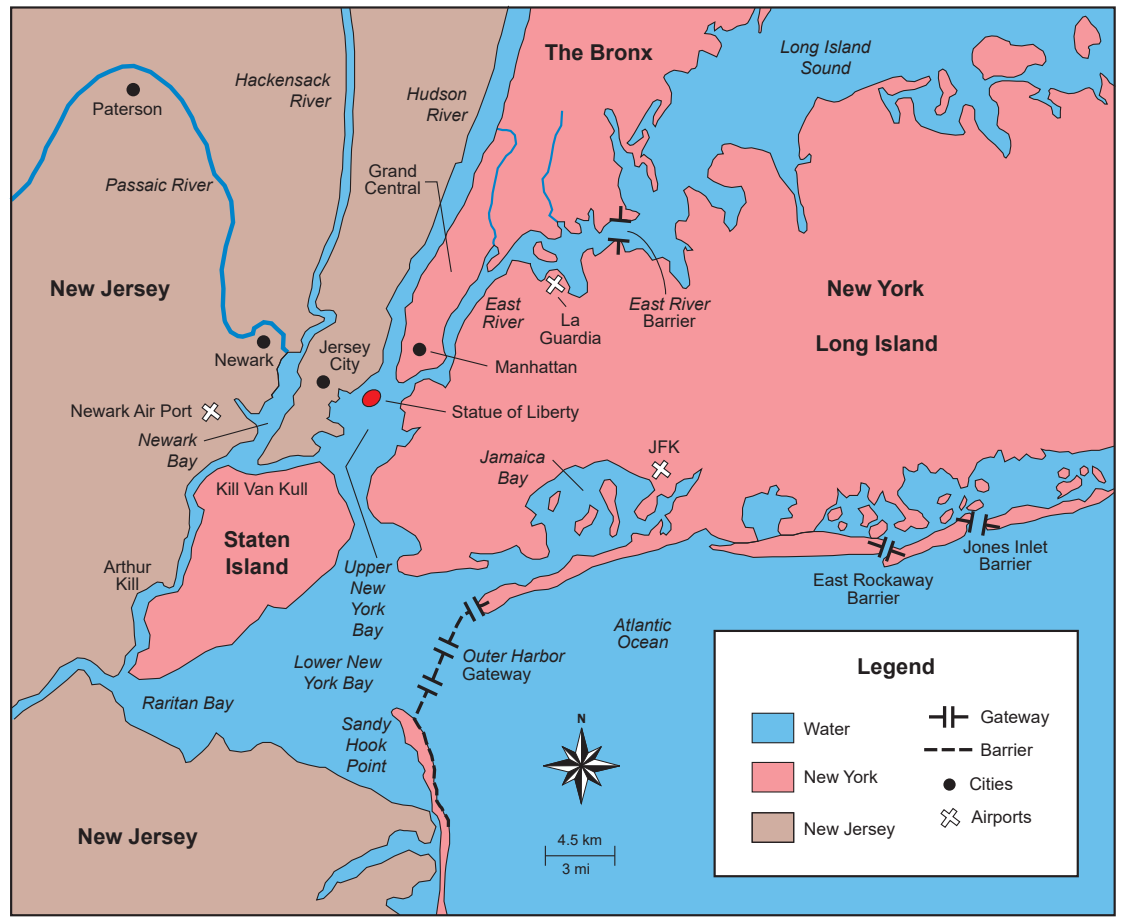

lion with a need for US $\$ 6$ billion more for cleanup and another US\$6 billion for natural resource restoration. The dioxin TCDDcontaminated sediment in the Passaic River has a very long half-life in sediment (Olson and Morton 2017, 2019) and remains an environmental and food supply problem in the Passaic River and Newark Bay. To this day, the harvesting of fish and crabs from the lower Passaic River is banned (New Jersey Department of Environmental Protection 2009). The sediment is still too contaminated with dioxin TCDD and remains a threat to both the food supply and human health.

\section{PASSAIC RIVER GEOLOGY AND HISTORY}

The Passaic River formed from a massive proglacial lake that developed in northern New Jersey approximately 13,000 years ago. The glacial ice sheet blocked the normal drainage path to the north. The overflowing lake drained out through the new path (figure 1), the present-day waterway to the ocean. The Passaic River now drains into the Newark Bay and flows parallel with the lower Hudson River along the west side of Staten Island and into Raritan Bay and the Atlantic Ocean.

The river is $120 \mathrm{~km}(80 \mathrm{mi})$ long with a $2,422 \mathrm{~km}^{2}\left(1,505 \mathrm{mi}^{2}\right)$ watershed and has been developed as a source of power and water. It flows into the Great Swamp lowland between the ridge hills of rural and suburban northern New Jersey. The Passaic River headwaters are in Mendham. The river flows south into Morristown

Kenneth R. Olson is a US Army Vietnam veteran and professor emeritus of soil science in the Department of Natural Resources, College of Agricultural, Consumer, and Environmental Sciences, University of Illinois, Urbana, IIlinois. Mike Tharp is a US Army Vietnam veteran who won a Bronze Star; he's a former Wall Street Journal and The New York Times reporter and experienced war correspondent. 
Natural Historical Park, passes through Lord Stirling Park, and then along the western side of the Great Swamp. The Passaic River drains northeast to Paterson and over the Great Falls of Passaic (figure 2) and into Dundee Lake. The Dundee Dam was built in 1845 . Approximately 4 $\mathrm{km}$ (2.4 mi) below the dam, the river is navigable to Raritan Bay before emptying into the Atlantic Ocean.

The Passaic flows through the most industrialized and urbanized areas of $\mathrm{New}$ Jersey. The lower river suffered industrial abandonment (figure 3) and severe pollution in the twentieth century. The chemical manufacturing site is on the floodplain and subject to erosion of the soil and sediment contaminated by toxic waste including dioxin TCDD, polychlorinated biphenyls (PCBs), and mercury (Hg) (Fallon 2019; Brickley and Morgenson 2018). During periods of heavy rainfall or snowmelt, the Passaic River has flooding problems-especially at the confluence of the Pompton and Passaic rivers. Historically, building has been allowed on these floodplains, which has resulted in homes and businesses now being frequently flooded. A plan has been proposed to build a 32 $\mathrm{km}$ (20 mi)-long flood tunnel to divert the periodic flood waters directly into Newark Bay (Romano 1992).

\section{DISCOVERY, FORMULATION, CREATION, AND MANUFACTURE OF THE HERBICIDE AGENT ORANGE DIOXIN TCDD IN THE PASSAIC RIVER VALLEY}

Hitchcock and Zimmerman at Boyce Thompson Institute (1935) found absorption and movement of synthetic growth substance from soil resulted in a response by the aerial part of the plant. In the 1940s botanists tried to initiate flowering by applying small quantities of various chemicals to different plants. Zimmerman and Hitchcock (1942) found that 2,3,5-triiodobenzoic acid (TIBA) induced flowering in tomato (Solanum lycopersicum L.) plants when either applied to soil or used as a spray on the leaves of the plants.

Arthur W. Galston's 1943 University of Illinois (botany) $\mathrm{PhD}$ thesis research focused on the use of TIBA to make soybeans (Glycine max [L.] Merr.) flower and fruit sooner so they could mature before the end of the growing season (Galston 1943). Galston also noted that in higher concentrations, it would cause soybeans to lose leaves. Galston's discovery led to the development of a precursor (TIBA) to Agent Orange (Olson and Morton 2019). In 1943 Galston moved to the California Institute of Technology to work with Nobel Prize winner George Beadle on World War II defense-related research. Galston joined the navy in 1944 and served as a natural resources officer while stationed in Okinawa, Japan, until World War II was over.

In 1951, biological warfare scientists at Fort Detrick, Maryland, began investigating the possible uses of defoliant herbicides based on Galston discoveries while working with TIBA. US military researchers eventually produced the toxic defoliant Agent Orange, which was used in the 1950s by the British air force during the Malayan Emergency and later in the 1960s by the US Air Force, Navy, and Army during the Vietnam War.

Since the 1940s, the 2,4-dichloro phenoxy acetic acid, $\mathrm{C}_{8} \mathrm{H}_{6} \mathrm{Cl}_{2} \mathrm{O}_{3} \quad(2,4-$ $\mathrm{D})$, and 2,4,5-trichloro phenoxy acetic acid, $\mathrm{C}_{8} \mathrm{H}_{5} \mathrm{Cl}_{3} \mathrm{O}_{3}(2,4,5-\mathrm{T})$, herbicides were used separately in the United States (Olson and Morton 2019). Agent Orange, a 50:50 mixture of 2,4-D and 2,4,5-T, was only produced for the US military. Both of these herbicides have a relatively short half-life when exposed to sunlight. Unfortunately, the manufacturing process used to make 2,4,5-T created a by-product or contaminant dioxin, TCDD, which has a much longer half-life (50 to 100 years or more) (Olson and Morton 2019). The two herbicides, when buried under anaerobic conditions in the subsoil or attached to clay and organic matter particles transported as sediment, settle to the bottom of a river or lake. Initially, the dioxin TCDD contaminant levels were in the range of $0.05 \mathrm{ppm}$ (Sills 2014). However, to meet the needs of the US military, approximately $4.26 \times 10^{7} \mathrm{~L}\left(1.126 \times 10^{7} \mathrm{gal}\right)$, the Agent Orange combustion process was accelerated by increasing the temperature $5^{\circ} \mathrm{C}\left(9^{\circ} \mathrm{F}\right)$ (Olson and Morton 2019). As a consequence, the dioxin TCDD levels in Agent Orange increased to as high as $60 \mathrm{ppm}$, or 3,000 times higher than the

\section{Figure 2}

The Great Falls of the Passaic River.

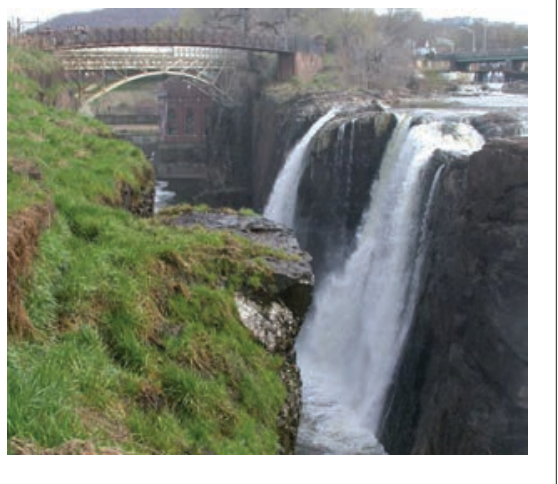

\section{Figure 3}

The gravel parking lot where the chemical plant was removed in Newark, New Jersey, along the Passaic River. The floodwall is visible in the background.

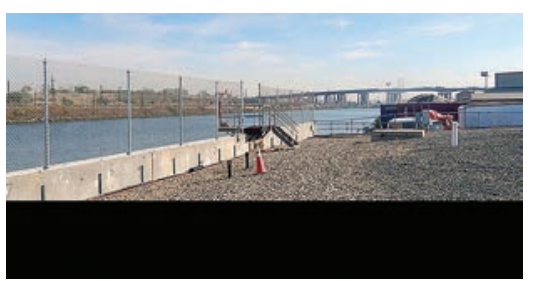

original Agent Orange by-product contaminant levels (Sills 2014). Military field tests, including some in Florida, were conducted with Agent Orange that was manufactured in the 1960s (Young and Newton 2004).

The US government passed the Defense Production Act in 1950. The government, as a nation at war, compelled 11 companies to create, produce, and supply Agent Orange to the military. From 1965 to 1969,11 wartime government contractors that manufactured Agent Orange only produced it for the US military (Olson and Morton 2019), and it was not sold to the public. These companies included Dow Chemical, Monsanto Company, Hercules Inc., Diamond Shamrock Corporation (previously Diamond Alkali), Hooker Chemical Company, Riverdale Chemical Company, Ansul Chemical Company, Uniroyal Inc., Occidental Chemical Company, N.A. Phillips Chemical Company, and Thompson-Hayward Chemical Company. The US government 
also specified how Agent Orange would be produced and then controlled its transportation, storage, distribution, and use.

During the manufacturing process, the workers at the New Jersey Diamond Alkali facility on the Passaic River were exposed to TCDD. Agent Orange was stored on site at Diamond Alkali in 205 L (55 gal) barrels painted with an orange stripe and then loaded on ocean-going ships (figure 4) headed for the South China Sea and the coast of Vietnam. The barrels were shipped and stored on military bases for spraying the jungle and food crops or on navy ships (figure 5) for use on stream banks and mangrove forests.

\section{RECOGNITION OF HARMFUL AGENT} ORANGE EFFECTS

Early in 1965 many scientific organizations, led by Arthur W. Galston (then a professor at Yale University), warned the US government against the military herbicide program. In all, 5,000 scientists, including members of the Federation of American Scientists and American Association of the Advancement of Science, along with 17 Nobel Prize winners, petitioned the US military and government to stop the use of chemical and biological weapons. Galston strongly objected to the use of his early scientific discovery and research in the development of the toxic herbicides for use in the Vietnam War (Galston 2009). He thought it was a misuse of science and stated, "Science is meant to improve the lot of mankind, not diminish it-and its use as a military weapon was ill-advised," in a California Institute of Technology Archives Oral History Project (Cohen 2002). Professor Galston was eventually recognized in 2004 by the University of Illinois Alumni Association for his scientific discovery and subsequent efforts to prevent its misuse by the US government and military.

By 1953, the chemical companies, including BASF, had also discovered the dioxin TCDD health effects on workers after an explosion (Zober et al. 1990) but were slow to inform the US government and military of the extent and magnitude of the dioxin TCDD contaminant in Agent Orange after the combustion temperature was raised $5^{\circ} \mathrm{C}\left(9^{\circ} \mathrm{F}\right)(\mathrm{Olson}$ and Morton

\section{Figure 4}

The loading of ocean-going ships at a port on the linked tidal Passaic and Hudson rivers system.

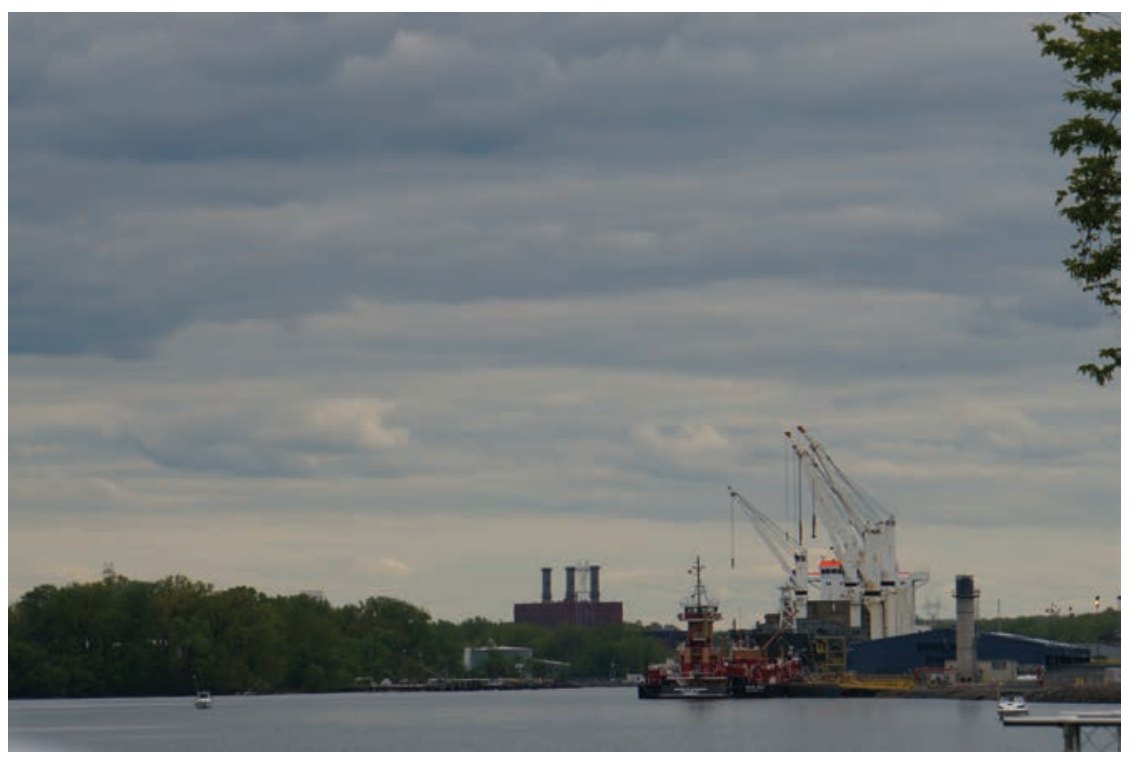

2019; Sills 2014). Dioxin TCDD by-product was also in other Rainbow herbicides with associated risks to the environment and human health (NAS 1974; Sills 2014). This delay in notifying the US government and military may have increased the 11 chemical companies' past, current, and future legal exposure (Olson and Morton 2019).

By the late 1960s, the US government and military became fully aware of the environmental and health consequences

of the contaminant dioxin TCDD (Zober et al. 1990; Institute of Medicine 1994; US Congress House of Representatives 1992). In 1970 President Nixon, acting in his role as Commander-in-Chief, ordered the US military to stop spraying Agent Orange. The next year, he ordered all Rainbow herbicide spraying, including Agent Blue, to be stopped and removed from Vietnam. Agent Orange barrels were collected at Bien Hoa Airbase (about 32

\section{Figure 5}

Navy ships that were used to transfer the chemicals from the commercial ships to the brown navy to spray on the stream banks.

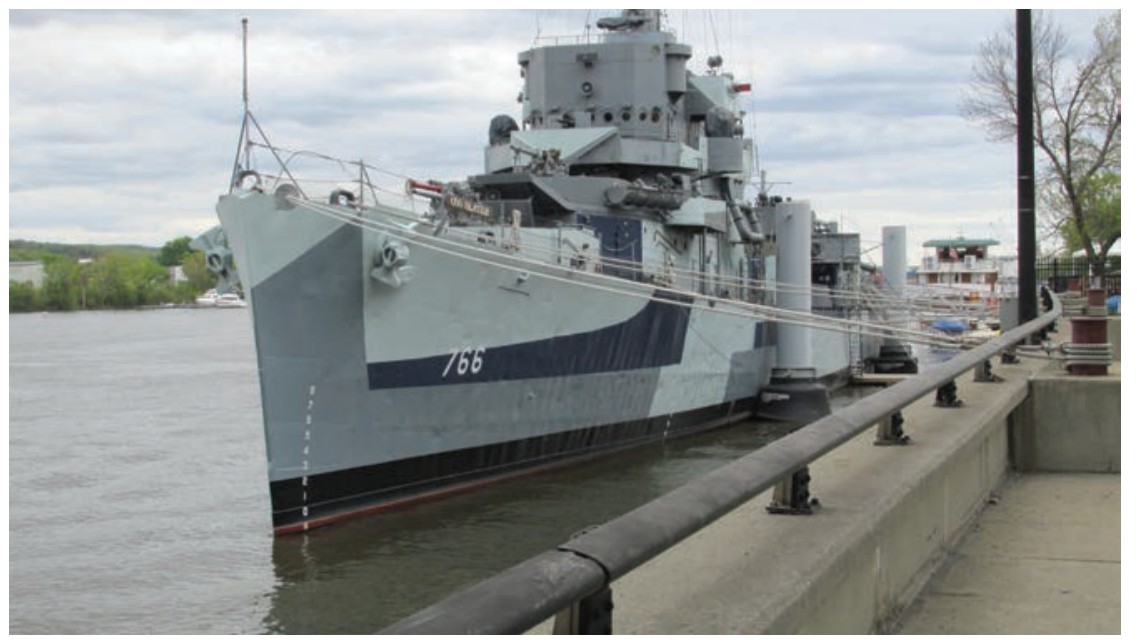


km [20 mi] northeast of Saigon/Ho Chi Minh City) from all the military airbases in Vietnam and shipped to Atoll Johnston Island in the Pacific Ocean. Many of the barrels were leaking and had to be resealed. This exposed the barrel handlers and transporters to dioxin TCDD. Agent Orange with high levels of dioxin TCDD either leached into the ground or was carried by runoff water into the waterways, streams, rivers, ponds, and lakes (Olson and Morton 2019). During the dry season, dioxin TCDD-contaminated dust from the perimeter road and border fence was blown into the adjacent landscapes. Fifty years after the US military stopped spraying Agent Orange, there is still a fish and shrimp ban on a lake outside the Bien Hoa Airbase hotspot, the most contaminated hotspot in Vietnam. The dioxin TCDD attached to the sediment, which then settled at the bottom off the lake. Bottom-feeding fish and mollusks then fed off the floor of the lake, and the dioxin TCDD was ingested and concentrated in their tissue. When contaminated fish and shrimp are eaten, it can still get into the current food supply and increases human health risks. Research by the United States. Department of Defense later led to the discovery that the contaminant TCDD in Agent Orange caused birth defects in laboratory rats (NAS 1974).

\section{THE SOURCE OF DIOXIN TCDD CONTAMINANT IN PASSAIC RIVER SEDIMENTS: DIAMOND ALKALI FACILITY IN NEWARK, NEW JERSEY}

In the 1940s, the Diamond Alkali facility in Newark, New Jersey, and on the banks of the Passaic River, was used to manufacture DDT and other chemical products. In the 1950s Diamond Alkali began to manufacture Agent Orange. Diamond Alkali workers stated in court testimony that they were exposed to Agent Orange by-product dioxin TCDD. These workers claimed that the factory floors in the 1950 s and 1960s were so slick with spilled and leaking Agent Orange and TCDD that it was treacherous to walk on them. The contaminant TCDD was washed by poorly protected workers into trenches and flowed into drains and pipes, which emptied into the Passaic River, a tidal river. In 1971, Diamond Alkali sold the Lister Avenue, New Jersey, facility. The Passaic River carried dioxin TCDD both upstream and downstream, contaminating a $27 \mathrm{~km}$ (17 mi)-section of the riverbed in one of New Jersey's most populated area and linked to Kill Van Kull (figure 1) and adjacent to the Hudson River and New York City. The dioxin-contaminated sediment has reached Newark Bay (figure 1), which is connected by the Kill Van Kull to the Hudson River just north of Staten Island.

The Port Authority of New York and New Jersey has spent millions dredging dioxin TCDD-contaminated soil and sediment from the port. Dioxin TCDD binds to the clay and soil organic matter (Olson and Morton 2019) and can be transported to the Passaic River during periods of heavy rainfall. Before 1998, floodwalls and slurry walls had been constructed (figure 3) to reduce the runoff sediment transport into the Passaic River and Newark Bay.

\section{SOILS AND SEDIMENT SAMPLING FOR DIOXIN TCDD}

In 1983, sampling of soils and sediments by the State of New Jersey and US Environmental Protection Agency (USEPA) near 80 Lister Avenue in Newark and in the Passaic River revealed high levels of dioxin TCDD (Mansnerus 1998). There were also high levels of PCBs and $\mathrm{Hg}$ as a consequence of the manufacture of other chemical products. In 2001, the USEPA, in partnership with New Jersey and other federal agencies, cleaned up the Lister Avenue manufacturing site. The building was torn down and hauled to a landfill, and the site became a gravel parking lot (figure 3); the dioxin-contaminated soil was removed and incinerated. Today only a gravel lot remains as part of an abandoned industrial complex. The remediation actions taken in the Passaic River included a pre-1998 floodwall and subsurface treatment system. The contaminated sediment in the river originating at the Lister site and neighboring lots was capped to prevent additional release of dioxin TCDD to the river. The site has been monitored by Occidental Chemical Corporation (Brickley and Morgenson 2018; Fallon 2019).
In 2005 the State of New Jersey sued Maxus Energy Corporation (the US unit of Argentina's oil giant YPF Sociedad Anomima) and OxyChem over a delay in the cleanup. The US $\$ 220$ million that the state spent cleaning up a section of the river was recovered from Maxus and OxyChem partnership under terms of a court settlement (Baxter 2011). Cleanup activities by the partnership in 2012 and 2014 included the removal and disposal of dioxin TCDD, PCBs, and $\mathrm{Hg}$-contaminated soils and sediment from two areas along the Passaic River (Grant 2011). The most concentrated inventory of dioxin TCDD contaminated sediment was adjacent to the Lister Avenue site, and it was dredged by Tierra Removal. At river mile 10.9 the highly concentrated inventory of highly contaminated mudflat on the east bank of the river near Lyndurst was dredged and capped (Baxter 2011; Brickley and Morgenson 2018). The Passaic River is one of the most polluted hotspots in the United States and site of one of the largest cleanup efforts ever. In 2014 the USEPA announced a US $\$ 1.7$ billion plan to remove $3.2 \times 10^{6} \mathrm{~m}^{3}\left(1.13 \times 10^{8} \mathrm{ft}^{3}\right)$ of toxic sediment contaminated with dioxin TCDD, PCBs, and Hg (USEPA 2019).

The sediments in the lower $13 \mathrm{~km}$ (8 $\mathrm{mi})$ of the Passaic River were found to be a major source of the contamination in other sections of the Passaic River and Newark Bay. In March of 2016 a remedy for the contaminated sediment of the lower Passaic River was chosen and included an engineering cap which was installed from bank to bank. In an attempt to avoid increasing the future flooding hazard and maintaining the navigation channel, part of the dioxin TCDD-contaminated sediment had to be removed to make room for the cap. The removed dredge material was dewatered and transported by barge to a sedimentpermitted processing facility on the banks of the Passaic River and Newark Bay for disposal (Grant 2011; Fallon 2019; Baxter 2011). The estimated cost was US $\$ 1.38$ billion. The USEPA estimated the cost of the cleanup of the lower $27 \mathrm{~km}$ (16 mi) of the Passaic River and Newark Bay (figure 1) to be US\$6 billion, in addition to US\$6 billion in earlier natural resource damages. Cleanups for the remainder of Newark 
Bay and lower Passaic River are still being planned (Brickley and Morgenson 2018; Fallon 2019).

Exposure to even low levels of contaminants through crab and fish consumption may have long-lasting health effects on people living along the lower Passaic River. The USEPA alerted the public about the prohibitions and advisories on harvesting crabs or fish in the tidal Passaic River and Newark Bay. The advisories and prohibitions are based on levels of $\mathrm{Hg}, \mathrm{PCBs}$, and dioxin in tested crabs and fish and are difficult to enforce.

\section{SUMMARY AND CONCLUSIONS}

The Passaic River parallels the Hudson River and was an industrial river, which included plants that manufactured Agent Orange that was used in the Vietnam War in the 1960s. Stretches of river along Newark are postindustrial, abandoned landscapes, and the sediment at the mouth of the Passaic River near Newark Bay remains contaminated with dioxin TCDD, PCBs, and $\mathrm{Hg}$. The USEPA designated a $27 \mathrm{~km}(16 \mathrm{mi})$ stretch of the Passaic River as a Superfund site. In 2013 several corporations agreed to pay New Jersey US $\$ 130$ million for ecological damages related to the Passaic River pollution (Baxter 2011). To date, US $\$ 1.38$ billion have been spent on cleanup. The USEPA estimated the remaining cost of cleanup of the lower Passaic River and Newark Bay at US $\$ 6$ billion in addition to US $\$ 6$ billion for past natural resource damages. After 50 years, US companies, such as Diamond Alkali (now Diamond Shamrock), stopped manufacturing Agent Orange with the by-product dioxin TCDD. However, the contaminant with a very long half-life when attached to sediment under anaerobic conditions remains an environmental problem in the tidal Passaic River and Newark Bay. To this day fish and crabs from the Passaic River are too contaminated with dioxin TCDD for human consumption and remain a threat to the food supply and human health (New Jersey Department of Environmental Protection 2009).

\section{ACKNOWLEDGEMENTS}

Published with funding (Hatch Project 875-979) and support from USDA National Institute of Food and Agriculture, Water Division, and the Director of the Illinois Office of Research, College of Agricultural, Consumer, and Environmental Science, University of Illinois, Urbana, Illinois.

\section{REFERENCES}

Baxter, C. 2011. Second New Jersey chemical company held liable for lower Passaic River pollution cleanup. NorthJersey.com

Brickley, P., and G. Morgenson. 2018. Agent Orange legacy - A $\$ 12$ billion cleanup and fight over who pays. Wall Street Journal, December 3, 2018 Cohen, S.K. 2002. Galston, Arthur, W. Oral History Project. Pasadena, CA: California Institute of Technology Archives.

Constable, J.D., and M.C. Hatch. 1985. Reproductive effects of herbicide exposure in Vietnam recent studies by the Vietnamese and others. Teratogenesis, Carcinogenesis, and Mutagenesis 5(4):231-250

Fallon, S. 2019. EPA targets Bergen, Passaic counties for Passaic River dioxin cleanup. But is it enough? July 30, 2019. NorthJersey.com.

Galston, A.W. 1943. The physiology of flowering with especial reference to floral initiation in soybeans. PhD Thesis. University of Illinois.

Galston, A.W. 2009. An accidental plant biologist. Plant Physiology 128(3): 786-781.

Grant, M. 2011. Environmentalist, official argue intent of 130 million to be obtained from Passaic River Polluters. NorthJersey.com.

Hitchcock, A.E., and P.W. Zimmerman. 1935. Absorption and movement of synthetic growth substances from soil as indicated by the responses of aerial plant parts. Contrib. Boyce Thompson Institute 1:447-476.

Institute of Medicine (US). 1994. Veterans and Agent Orange: Health Effects of Herbicides Used in Vietnam. Washington, DC: National Academy Press.

Mansnerus, L. 1998. Newark's toxic tomb; Six acres fouled by dioxin, Agent Orange's deadly byproduct, reside in the shadow of an awakening downtown. The New York Times. Nov. 8, 1998.

NAS (National Academy of Sciences). 1974. The effects of herbicides in South Vietnam: Part A. Summary and Conclusions. Washington, DC: National Academy of Sciences.

New Jersey Department of Environmental Protection. 2009. Notice to general public - fish should not be eaten. Fish Advisory posted January 23, 2009.
Olson, K.R., and L.W. Morton. 2017. Why were the soil tunnels of $\mathrm{Cu} \mathrm{Chi}$ and Iron Triangle in Vietnam so resilient? Open Journal of Soil Science 7:34-51.

Olson, K.R., and L.W. Morton. 2019. Long-term fate of Agent Orange and dioxin TCDD contaminated soils and sediments in Vietnam hotspots. Open Journal of Soil Science 9(1):1-34.

Romano, J. 1992. Passaic Flood Tunnel: A turning point. The New York Times, November 8, 1992.

Schecter, A., L.C. Dai, L.T. Thuy, H.T. Quynh, H.D. Cau, P.H. Phiet, N.T. Nguyen, J.D. Constable, and R. Baughman. 1995. Agent Orange and the Vietnamese: The persistence of elevated dioxin levels in human tissues. American Journal of Public Health 85(5):516-522.

Sills, P. 2014. Toxic War: The Story of Agent Orange. Nashville, TN:Vanderbilt University Press.

Stockbauer, J.W., R.E. Hoffman, W.F. Schramm and L.D. Edmonds. 1988. Reproductive outcomes of mother's with potential exposure to 2,3,7,8-T dioxin. American Journal of Epidemiology 128:410-419.

Thomas, T.L., and H.K. Kang. 1990. Mortality and morbidity among Army Chemical CorpsVietnam Veterans: A preliminary report. American Journal of Industrial Medicine 18:665-67.

USEPA (US Environmental Protection Agency). 2019. Case Summary: US $\$ 165$ million settlement to start cleanup work on the Passaic River in New Jersey. Washington, DC: US Environmental Protection Agency.

US Congress House of Representatives. 1992. Committee on Government Operations, Human Resources Intergovernmental Relations Subcommittee. Hearing on Health Risks of Dioxin. June 10, 1992.

Young,A.L., and M. Newton. 2004. Long overlooked historical information on Agent Orange and TCDD following massive applications of 2,4,5-T containing herbicides. Eglin Air Force Base, Florida. Environmental Science and Pollution Research 11:209-221. https://doi.org/10.1007/ BF02979627.

Zimmerman, P.W., and A.E. Hitchcock. 1942 Flowering habit and correlation of organs modified b triiodobenzoic acid. Contrib. Boyce Thompson Institute 12:491-496.

Zober, A., P. Messerer, and P. Huber. 1990. Thirtyfour year mortality follow-up of BASF employees exposed to 2,3,7,8-T dioxin after 1953 accident. International Archives of Occupational and Environmental Health 62(2):139-157. 


\section{Erratum for Olson and Tharp, How did the Passaic River, a Superfund site near Newark, New Jersey, become an Agent Orange dioxin TCDD hotspot?}

Volume 75(2), p. 33A: Lines 1-6 in the Author Information box should read as follows: "Kenneth R. Olson is a US Army Vietnam Era veteran and professor emeritus of soil science in the Department of Natural Resources, College of Agriculture Consumer and Environmental Sciences, University of Illinois, Urbana, Illinois."

\section{Reference}

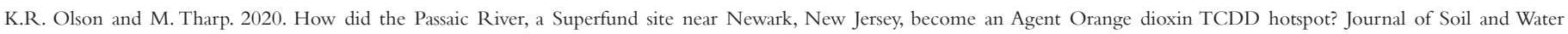
Conservation 75(2):33A-37A, DOI: https://doi.org/10.2489/jswc.75.2.33A. 